\title{
MUHAMMADIYAH DAN POLITIK: LANDASAN IDEOLOGI BAGI ARTIKULASI KONSTRUKTIF
}

\author{
Pramono U. Tanthowi
}

\begin{abstract}
Abstrak
Selama era reformasi, muncul beberapa kecenderungan perilaku politik baru yang menuntut Muhammadiyah untuk melakukan reorientasi pada sisi pemikiran politik. Ini menunjukkan bahwa sejak awal Muhammadiyah telah menegaskan sikapnya sebagai gerakan sosial keagamaan yang memilih strategi non-politik. Namun di sisi lain reformasi telah membuka peluang bagi setiap kekuatan politik untuk berkontestasi dan memperjuangkan kepentingannya melalui proses demokratis. Perbedaan pandangan tentang bagaimana Muhammadiyah terlibat dalam politik kekuasaan bukanlah sesuatu yang baru. Tulisan ini ingin menjelaskan bahwa Muhammadiyah merupakan salah satu komponen bangsa yang memiliki posisi dan peran yang sangat strategis. Muhammadiyah dapat memainkan peran politik sebagai kekuatan politik yang ikut memengaruhi proses politik nasional secara signifikan, tanpa harus mengubah jati dirinya menjadi organisasi partai politik.
\end{abstract}

Kata kunci : Muhammadiyah, Reformasi, Politik Elektoral, Orde Baru 
"Memang politik dan Islam tidak dapat dipisahkan, sebagaimana halnya gula dan rasa manisnya yang tak mungkin dipisahkan. Begitu pula antara agama dan politik. Hanya semenjak jatuhnya kerajaan Islam di Andalusia, semenjak itu pula tangan Islam merasa tidak laras lagi dalam memegang politik. Lamakelamaan umat Islam tidak mengerti sama sekali apa arti politik itu. ...Padahal perintah Tuhan, umat Islam harus cakap mengurus segala kebutuhan hidup di dunia sampai di akhirat nanti."1

"Muhammadiyah tidak berbuat atau berhubungan dengan politik atau urusan negeri. Akan tetapi Muhammadiyah memperbaiki budi pekerti dan kepercayaan segala manusia, sehingga menjadi baik adanya sebagaimana telah disuruhkan dan dikerjakan sendiri oleh Nabi Muhammad. Sikap Muhammadiyah kepada persyarikatan politik tidak menghalang-halangi."2

Perbedaan pandangan tentang bagaimana Muhammadiyah terlibat dalam politik kekuasaan bukanlah sesuatu yang baru. Dua kutipan di atas dengan jelas menggambarkan bahwa telah sejak lama muncul kelompok yang mendorong agar Muhammadiyah menyatakan sikap dan artikulasi politiknya secara lebih tegas. Di sisi lain juga ada sekelompok orang yang berpandangan bahwa Muhammadiyah harus konsisten dengan tujuan berdirinya, yakni fokus pada kerja-kerja sosial-keagamaan yang bersifat non-politik.

Perbedaan pandangan seperti ini terus berulang. Terutama selama era reformasi yang telah berlangsung sejak Mei 1998. Harus diakui bahwa reformasi telah mendatangkan liberalisasi dan relaksasi politik. Runtuhnya rezim Orde Baru yang sangat sentralistik dan hegemonik membuat "kotak pandora" terbuka lebar. Apa yang selama Orde Baru tersimpan rapat di bawah karpet, telah mencuat kembali. Itu semua merupakan ekspresi psikologis masyarakat yang wajar, karena membutuhkan ruang publik yang memadai.

Memang harus diakui bahwa selama era reformasi telah muncul beberapa kecenderungan perilaku politik baru yang menuntut Muhammadiyah untuk melakukan reorientasi pada sisi pemikiran politik. Ini mengingat bahwa

1 Soebagyo, LN., KH Mas Mansur Pembaharu Islam Indonesia, (Jakarta: Gunung Agung, 1982), h. 36.

2 Pernyataan K.H. Fachruddin dalam "Muhammadiyah dan Politik", dalam DepartemenPenerangan RI, Makin Lama Makin Tjinta: Muhammadiyah Setengah Abad 1912-1262, (Jakarta: Departemen Penerangan, 1963), h. 201. 
sejak awal Muhammadiyah telah menegaskan sikapnya sebagai gerakan sosial keagamaan yang memilih strategi non-politik. Namun di sisi lain reformasi telah membuka peluang bagi setiap kekuatan politik untuk berkontestasi dan memperjuangkan kepentingannya melalui proses demokratis. ${ }^{3}$

Pertama, menguatnya partisipasi politik warga Muhammadiyah sejak era reformasi. Terutama setiap kali berlangsung momentum politik elektoral, baik Pemilu Legislatif, Pemilu Presiden/Wakil Presiden, maupun Pilkada. Di satu sisi, ledakan partisipasi politik warga Muhammadiyah merupakan wujud komitmen kebangsaan organisasi ini. Selain itu, partisipasi politik ini juga berguna untuk mengasah kembali kepekaan politik warga Muhammadiyah yang terlumpuhkan selama era Orde Baru. Namun di sisi lain, partisipasi ini hingga batas tertentu telah menimbulkan gesekan dan konflik kepentingan dalam organisasi Muhammadiyah karena perbedaan pilihan politik yang keras. ${ }^{4}$

Kedua, kelahiran partai-partai politik baru sejak awal era reformasi hingga Pemilu 2019 yang lalu harus diakui cukup mengimbas ke dalam tubuh Muhammadiyah. Terutama partai-partai politik yang dibidani oleh para mantan elitee aktivis Muhammadiyah. Lahirnya beragam partai politik tersebut, baik yang berasas Islam, terbuka, maupun "sekuler", menimbulkan perdebatan teologis yang cukup marak di Muhammadiyah. Hal ini tentu menuntut Muhammadiyah untuk memberi jawaban, bagaimana sesungguhnya umat Islam (dan warga Muhammadiyah) harus berpolitik di tengah realitas sosial politik yang majemuk di Indonesia.

Ketiga, pandangan mengenai politik memunculkan dua kecenderungan yang kontras. Sebagian warga Muhammadiyah mencoba untuk konsisten dalam memahami dan menerapkan Khittah Denpasar 2002, sehingga cenderung menganggap politik adalah bagian dari persoalan keduniaan yang penuh kepentingan pragmatis. Hal ini tentu berbenturan dengan sebagian warga Muhammadiyah lain yang terlibat aktif dalam politik kekuasaan, yang memandang perjuangan politik adalah bagian dari jihad keagamaan, dan

3 Lihat, Haedar Nashir, Perilaku Politik Elite Muhammadiyah, (Yogyakarta: Tarawang, 2000), h. 216-217.

4 Pada awal reformasi Rusydi Hamka, salah satu Anggota PP Muhammadiyah mengeluh karena merasa disisihkan oleh sebagian warga Muhammadiyah, hanya karena dia masih berada di PPP. Bahkan, banyak jadwal khutbah beliau yang dibatalkan pengelola Masjid Muhammadiyah karena sebagian besar warga Muhammadiyah merupakan pendukung PAN. Pada Pemilu 2019 yang lalu, juga muncul ketegangan yang sangat luas di kalangan warga Muhammadiyah akibat polarisasi dukungan Pasangan Capres/Cawapres. 
menentukan apakah seseorang tergolong kaum Muslim atau kafir. Karena itu, Muhammadiyah dituntut untuk meluruskan pemahaman tentang politik agar warga Muhammadiyah tidak terjebak pada pandangan yang keliru dalam memahami dan menyikapi politik.

Keempat, independensi politik Muhammadiyah (sebagai hasil dari keputusan Khittah Perjuangan Muhammadiyah) yang semakin terancam tidak saja dari partai-partai politik, tetapi juga dari kekuatan-kekuatan politik lain. Sebagian warga Muhammadiyah yang terlibat dalam politik kekuasaan telah dengan sengaja menempatkan struktur organisasi dan Amal Usaha Muhammadiyah sebagai basis mobilisasi pemenangan dalam politik elektoral. Bahkan lebih jauh lagi, sebagian dari mereka telah menempatkan tokoh-tokoh yang tidak memiliki kualifikasi yang memadai, baik dalam aspek keulamaan dan intelektualitas sebagai imam dan panutan dalam mengambil keputusan-keputusan politik. Karena itu perlu dirumuskan konsep baru tentang "netralitas" yang sesuai dengan kebutuhan zaman, sehingga Muhammadiyah dapat memainkan peranperan politik baru dalam kancah nasional serta memiliki kewibawaan dan pengaruh yang diperhitungkan.

Kelima, mengenai artikulasi dan fungsi politik Muhammadiyah. Dinamika politik Islam kontemporer diwarnai dengan munculnya gerakan-gerakan baru yang sangat artikulatif di luar partai-partai politik dan wadah politik formal lain. Jika tidak ingin kehilangan wilayah garapan, atau bahkan terjebak pada wilayahwilayah garapan tradisional (pendidikan, kesehatan, dan pelayanan sosial), maka Muhammadiyah harus mampu memainkan peran-peran politik kualitatif dalam kapasitasnya sebagai organisasi sosial-keagamaan yang berwibawa.

Mempertimbangkan situasi sosial-politik kontemporer sebagaimana dipaparkan di atas, tampaknya penting bagi Muhammadiyah untuk merumuskan kerangka pemikiran yang mendasar mengenai politik, ketika dunia politik Indonesia dewasa ini dan di masa depan cenderung mengarah pada menguatnya politik elektoral yang semakin pragmatis. Pemikiran politik Muhammadiyah sebagai landasan bagi pandangan-dunia Muhammadiyah mengenai kehidupan politik menjadi sangat penting bagi Muhammadiyah bukan saja sebagai acuan perilaku politik warga dan elite Muhammadiyah tetapi juga bagi kepentingan pertukaran dan pencerahan pemikiran di tengah lalu lintas pemikiran yang beragam di Indonesia. 
Oleh karena itu maka tulisan ini dimaksudkan untuk merumuskan pandangan politik Muhammadiyah dengan merujuk pada dokumen-dokumen resmi yang selama ini menjadi landasan ideologis organisasi ini. Perlu ditekankan di sini bahwa kajian tentang relasi antara Muhammadiyah dan politik telah dilakukan oleh para pengamat sejak lama, seperti Alfian, ${ }^{5}$ Syamsuddin, ${ }^{6}$ Syaifullah, ${ }^{7}$ Nashir, ${ }^{8}$ dan sebagainya. Namun kajian-kajian tersebut lebih difokuskan pada peran dan keterlibatan organisasi tersebut dalam politik kekuasaan dalam periode tertentu dalam sejarah Indonesia, sejak masa pendudukan Jepang, era Orde Lama, hingga era Orde Baru.

Di sisi lain, terdapat beberapa studi lain yang lebih menitikberatkan kajiannya pada peran Muhammadiyah dalam politik elektoral di era reformasi. Misalnya tulisan Jung yang menyatakan bahwa perilaku politik Muhammadiyah di era reformasi lebih ditentukan oleh logika institusional, yang mendahulukan tugas-tugas sosial-keagamaan dibanding kepentingan politiknya. ${ }^{9}$ Demikian juga kajian Sulistiyanto yang membahas tentang peran Muhammadiyah dalam membentuk identitas politik lokal di Kotagede, Yogyakarta di era reformasi. ${ }^{10}$

Berbeda dengan kajian-kajian yang telah disebutkan di atas, tulisan ini dimaksudkan untuk melacak gagasan-gagasan Muhammadiyah tentang agama, masyarakat, politik dan kekuasaan yang terkandung dalam keputusan-keputusan yang telah diambil oleh Muhammadiyah. Dari gagasan-gagasan yang terpisah itu akan dirumuskan sebuah benang merah tentang bagaimana Muhammadiyah merumuskan pedoman perilaku bagi para warganya dalam melihat dan terlibat dalam politik kekuasaan.

5 Alfian, Muhammadiyah: The Political Behaviour ofA Muslim Modernist Organization under Dutch Colonialism, (Yogyakarta: Gajah Mada University Press, 1989).

6 M. Din Syamsuddin, Religion and Politics in Islam: The Case of Muhammadiyah in Indonesia’s New Order, DisertasiDoktor di University of California Los Angeles, 1991.

7 Syaifullah, Gerak Politik Muhammadiyah dalam Masyumi, (Jakarta: Pustaka Utama Grafiti, 1997).

8 Haedar Nashir, Dinamika Politik Muhammadiyah, (Yogyakarta: Bigraf Publishing, 2000).

9 Eunsook Jung, "Islamic Organizations and Electoral Politics in Indonesia: The Case of Muhammadiyah," Southeast Asia Research, Vol. 22, No. 1, h. 73-86.

10 Priyambudi Sulistiyanto, "Muhammadiyah, Local Politics, and Local Identity in Kotagede," Sojourn: Journal of Social Issues in Southeast Asia, Vol. 21, No. 2, 2006, h. 254-270. 
Tulisan ini akan dimulai dengan tinjauan atas dokumen-dokumen resmi Muhammadiyah yang di dalamnya memiliki kandungan mengenai keputusankeputusan strategis-politis. Berikutnya akan dilakukan analisis sehingga keputusan-keputusan tersebut dapat disusun menjadi sebuah rumusan yang menyeluruh tentang bagaimana Muhammadiyah memandang politik kekuasaan. Dan bagian berikutnya, dari dokumen-dokumen resmi tersebut juga akan disusun sebuah panduan mengenai bagaimana warga Muhammadiyah mengartikulasikan sikapnya dalam kancah politik kekuasaan.

\section{Sumber-sumber Ideologis}

Jika mengkaji dokumen-dokumen yang memuat paham keagamaan resmi Muhammadiyah, memang agak sulit untuk menemukan sebuah konsep yang lengkap dan sistematis mengenai pemikiran mendasar Muhammadiyah mengenai politik. Demikian juga dengan pemikiran para tokohnya. ${ }^{11} \mathrm{Hal}$ ini secara sekilas menunjukkan sebuah kesan bahwa Muhammadiyah tidak memiliki ketertarikan dalam mengembangkan wacana mengenai masalah sosial-kemasyarakatan, khususnya tentang pemikiran politik.

Namun jika dikaji lebih lanjut, hal ini sebenarnya merupakan akibat dari corak gerakan pembaruan Muhammadiyah yang, menurut Amin Abdullah, bercorak "a faith in action". ${ }^{2}$ Dengan corak demikian, maka gerakan pembaruan Muhammadiyah selama ini tidak terlalu tertarik untuk mengembangkan wacana pemikiran, tetapi lebih berorientasi untuk menggabungkan dimensi teologis-filosofis sekaligus menekankan pada dimensi sosial-praksis. Maka dalam sejarah, ayat-ayat al-Qur'an tentang kemanusiaan yang diajarkan Kiai Dahlan kepada murid-muridnya, selalu tidak pernah terhenti pada hafalan dan pemahaman, namun dituntut untuk dilaksanakan secara konkret. Dengan landasan seperti ini, Muhammadiyah terbukti mampu melahirkan lembagalembaga pendidikan, kesehatan, dan sosial dalam jumlah yang sangat massif.

Doktrin yang diambil Muhammadiyah dengan menggabungkan aspek teologisfilosofis dan sekaligus memberi penekanan lebih besar pada aspek sosial-praksis merupakan eksperimen umat Islam Indonesia untuk keluar dari pusaran

11 Haedar Nashir, Dinamika Politik Muhammadiyah, (Yogyakarta: Bigraf Publishing, 2000), h. 61 .

12 M. Amin Abdullah, Dinamika Islam Kultural, (Bandung: Mizan, 2000), h. 31-32. 
diskursus teologis sejak zaman klasik, yang notabene hanya bercorak rasionalintelektual an sich, ke arah wilayah yang bersifat historis-empiris-praksis.

Serpihan-serpihan pemikiran politik Muhammadiyah sebenarnya dapat dilacak dari seperangkat nilai-nilai ideologi dan doktrin yang merupakan hasil penafsiran atas Islam dan menjadi patokan dalam meraih cita-cita gerakan, yang secara representatif tertuang dalam seperangkat pemikiran yang mendasar dan menggambarkan formulasi cita-cita luhur Muhammadiyah. Pertama, Muqaddimah Anggaran Dasar Muhammadiyah. Kedua, Kepribadian Muhammadiyah. Ketiga, Keyakinan dan Cita-Cita Hidup Muhammadiyah. Keempat, Khittah Perjuangan Muhammadiyah. Kelima, Pedoman Hidup Islami Warga Muhammadiyah. Dan keenam, Khittah dalam Kehidupan Berbangsa dan Bernegara sebagai hasil keputusan Tanwir Muhammadiyah di Denpasar tahun 2002.

Jika melihat lebih dalam keenam formulasi tersebut, maka akan didapatkan beberapa rumusan pemikiran politik Muhammadiyah yang bersifat mendasar dan filosofis.

Pertama, sebagaimana termaktub dalam Matan "Mukaddimah Anggaran Dasar Muhammadiyah", dinyatakan bahwa "hidup bermasyarakat adalah sunnah Allah atas kehidupan manusia di dunia ini". Dan "masyarakat yang sejahtera, aman damai, makmur dan bahagia hanyalah dapat diwujudkan di atas (prinsip) keadilan, kejujuran, persaudaraan dan gotong-royong, bertolong-menolong dengan bersendikan hukum Allah yang sebenar-benarnya, lepas dari pengaruh syaitan dan hawa nafsu". ${ }^{13}$

Kedua, dalam Matan "Kepribadian Muhammadiyah", dinyatakan dengan jelas bahwa sifat Muhammadiyah adalah keagamaan dan kemasyarakatan. Muhammadiyah juga "aktif dalam perkembangan masyarakat dengan maksud ishlah dan pembangunan sesuai dengan ajaran Islam”. Selain itu, Muhammadiyah "membantu pemerintah serta bekerja sama dengan golongan lain dalam memelihara dan membangun negara untuk mencapai masyarakat yang adil dan makmur". Namun, juga ditegaskan bahwa Muhammadiyah "bersifat adil dan korektif ke dalam dan ke luar dengan bijaksana".14

13 Musthafa Kamal Pasha dan Ahmad Adaby Darban, Muhammadiyah sebagai Gerakan Islam dalam Perspektif Historis dan Ideologis, (Yogyakarta: LPPI, 2002), h. 185. 
Ketiga, dalam Matan "Keyakinan dan Cita-cita Hidup” juga dinyatakan bahwa "Muhammadiyah adalah gerakan berasas Islam, bercita-cita dan bekerja untuk terwujudnya masyarakat Islam yang sebenar-benarnya, untuk melaksanakan fungsi dan misi manusia sebagai hamba dan khalifah Allah di muka bumi”. Muhammadiyah juga "bekerja untuk terlaksananya ajaran-ajaran Islam yang meliputi bidang-bidang akidah, akhlak, ibadah, dan muamalah duniawiyah (pengelolaan dunia dan pembinaan masyarakat). Selain itu, juga dinyatakan bahwa "Muhammadiyah mengajak segenap lapisan bangsa Indonesia ... untuk berusaha bersama-sama menjadikan suatu negara yang adil, makmur, dan diridlai Allah." ${ }^{15}$

Keempat, dalam Khittah Perjuangan Muhammadiyah yang ditetapkan dalam Muktamar ke-38 di Makasar tahun 1971 ditegaskan, bahwa "Muhammadiyah adalah gerakan dakwah Islam yang beramal dalam segala bidang kehidupan manusia dan masyarakat, tidak mempunyai hubungan organisatoris dengan dan tidak merupakan afiliasi dari suatu partai politik atau organisasi apapun.” Selain itu "setiap anggota Muhammadiyah, sesuai dengan hak asasinya, dapat tidak memasuki atau memasuki organisasi lain, sepanjang tidak menyimpang dari AD/ART dan ketentuan-ketentuan lain yang berlaku dalam Persyarikatan Muhammadiyah."16

Kelima, dalam "Pedoman Hidup Islami Warga Muhammadiyah" di bagian Kehidupan dalam Berbangsa dan Bernegara, dinyatakan bahwa: ${ }^{17}$

- Warga Muhammadiyah perlu mengambil bagian dan tidak boleh apatis (masa bodoh) dalam kehidupan politik melalui berbagai saluran secara positif ... dengan prinsip-prinsip etika/akhlak Islam dengan sebaik-baiknya dengan tujuan membangun masyarakat Islam yang sebenar-benarnya.

- Beberapa prinsip dalam berpolitik harus ditegakkan dengan sejujurjujurnya dan bersungguh-sungguh dan prinsip-prinsip lain yang maslahat, ihsan, dan ishlah”.

15 Ibid., h. 288-289.

16 Yusuf Abdullah Puar, Perjuangan dan Pengabdian Muhammadiyah, (Jakarta: Pustaka Antara, 1989), h. 293.

17 PP Muhammadiyah, PedomanHidupIslamiWarga Muhammadiyah, (Yogyakarta: Suara Muhammadiyah, 2000). 
- Berpolitik dalam dan demi kepentingan umat dan bangsa sebagai wujud ibadah kepada Allah dan ishlah serta ihsan kepada sesama, dan jangan mengorbankan kepentingan yang lebih luas dan utama itu demi kepentingan diri sendiri dan kelompok yang sempit.

- Para politisi Muhammadiyah berkewajiban menunjukkan keteladanan diri (uswah hasanah) yang jujur, benar, dan adil serta menjauhkan diri dari perilaku politik yang kotor, membawa fitnah, fasad (kerusakan), dan hanya mementingkan diri sendiri.

- Berpolitik dengan kesalehan, sikap positif, dan memiliki cita-cita bagi terwujudnya masyarakat Islam yang sebenar-benarnya dengan fungsi amar makruf dan nahi munkar yang tersistem dalam satu kesatuan imamah yang kokoh.

- Menggalang silaturahmi dan ukhuwah antar politisi dan kekuatan politik yang digerakkan oleh para politisi Muhammadiyah secara cerdas dan dewasa.

Keenam, dalam Khittah Muhammadiyah dalam Kehidupan Berbangsa dan Bernegara dinyatakan, bahwa "Muhammadiyah memilih perjuangan dalam kehidupan berbangsa dan bernegara melalui usaha-usaha pembinaan dan pemberdayaan masyarakat guna terwujudnya masyarakat madani (civil society) yang kuat sebagaimana tujuan Muhammadiyah. Sedangkan hal-hal yang berkaitan dengan kebijakan-kebijakan kenegaraan sebagai proses dan hasil dari fungsi politik pemerintahan akan ditempuh melalui pendekatan-pendekatan secara tepat dan bijaksana sesuai prinsip-prinsip perjuangan kelompok kepentingan yang efektif dalam kehidupan negara yang demokratis.”

Selain itu "Muhammadiyah senantiasa memainkan peranan politiknya sebagai wujud dari dakwah amar makruf nahi munkar dengan jalan memengaruhi proses dan kebijakan negara agar tetap berjalan sesuai dengan konstitusi dan citacitaluhurbangsa”. Muhammadiyah juga "menjalankan fungsi kritik sesuai dengan prinsip amar makruf nahi munkar demi tegaknya sistem politik kenegaraan yang demokratis dan berkeadaban”. Juga, "Muhammadiyah memberikan kebebasan kepada setiap anggota Persyarikatan untuk menggunakan hak pilihnya dalam kehidupan politik sesuai hati nurani masing-masing. Penggunaan hak pilih tersebut harus ...dilaksanakan secara rasional dan kritis, sejalan dengan misi dan 
kepentingan Muhammadiyah, demi kemashlahatan bangsa dan negara.”18

Dari pemaparan di atas dapat dilihat bahwa Muhammadiyah sebenarnya telah merumuskan pandangannya mengenai politik dan memberikan panduan bagi para warganya tentang bagaimana menyikapi perkembangan politik yang berlangsung secara dinamis. Meskipun perlu ditegaskan sekali lagi, bahwa pandangan dan panduan tersebut berserakan dalam berbagai dokumen keputusan organisasi yang selama ini dijadikan sebagai landasan-landasan ideologis organisasi ini.

Pada bagian berikutnya, penulis akan menyusun sebuah kerangka tentang bagaimana Muhammadiyah memandang persoalan politik berdasar pada landasanlandasan ideologis sebagaimana dipaparkan di atas, sekaligus dikombinasikan dengan pengalaman bagaimana organisasi ini mengartikulasikan kepentingankepentingannya dalam kancah politik kekuasaan.

\section{Pandangan Politik Muhammadiyah}

Dari beberapa rumusan pemikiran politik sebagaimana diuraikan di bagian sebelumnya, kita dapat menarik sebuah kerangka pemikiran Muhammadiyah mengenai politik dan masalah kenegaraan lain. Kerangka pemikiran tersebut diharapkan dapat dipergunakan bagi Persyarikatan sendiri maupun bagi para warganya untuk mengartikulasikan kepentingan politiknya. Beberapa pemikiran politik yang dapat dijadikan landasan artikulasi politik Persyarikatan Muhammadiyah tersebut antara lain:

\section{Muhammadiyah Mmemilih Strategi Gerakan Kultural Dengan Menekankan Pada Pengingkatan Kualitas Individu dan Pemberdayaan Masyarakat}

Memang Muhammadiyah, sebagaimana dikatakan Voll, memang didirikan terutama sebagai organisasi yang bersifat sosial-budaya dan pendidikan, serta sebisa mungkin menghindari pergolakan politik. ${ }^{19}$ Untuk berpartisipasi dalam kehidupan berbangsa dan bernegara, Muhammadiyah mengambil peran dalam ranah kultural dan non-politik. Artikulasinya diwujudkan

18 PP Muhammadiyah, Berita Resmi Muhammadiyah, No. 02/2002, h. 19-21.

19 Haedar Nashir, Muhammadiyah Gerakan Pembaruan, (Yogyakarta: Suara Muhammadiyah, 2010). 
melalui kegiatan kemasyarakatan yang bersifat pembinaan dan pemberdayaan masyarakat. ${ }^{20}$ Bagi Muhammadiyah, aspek sosio-kultural yang mengarah kepada pemberdayaan masyarakat tidak kalah penting dan strategis dibanding perjuangan melalui ranah politik kekuasaan. Perjuangan dalam ranah kultural ini diarahkan untuk terbentuknya civil society sebagai pilar utama terbentuknya negara yang berkedaulatan rakyat.

Strategi kultural, menurut cendekiawan Muhammadiyah Kuntowijoyo, berusaha memengaruhi perilaku sosial (cara berfikir masyarakat). Cara pertama dari strategi kultural adalah penyadaran dan sifatnya individual (memengaruhi perorangan). ${ }^{21}$ Menurut Kuntowijoyo, kata kunci dari strategi kultural adalah agama sebagai moral force, atau inspirational (moral, etika, dan intelektual). Tujuan dari strategi kultural adalah mengubah cara berfikir perorangan, bukan berusaha mengubah kolektivitas. Lebih lanjut, Kuntowijoyo mengatakan bahwa pendekatan individual lebih awet daripada kolektif, karena kesadaran kolektif mudah dipengaruhi dari luar, baik berupa politik, ekonomi, informasi, dan budaya.

\section{Muhammadiyah Bersikap Netral-Aktif Terhadap Semua Kekuatan Politik}

Konsep netralitas dapat dimaknai dengan dua hal: tidak berafiliasi kepada kekuatan politik manapun serta independen terhadap negara (state). Sementara sikap aktif dapat diartikan sebagai partisipasi Muhammadiyah dalam memengaruhi proses pengambilan kebijakan negara agar terwujud masyarakat demokratis dan berkeadaban (democratic civility).

Meski sejakawal Muhammadiyah didirikan bukan untuk tujuan politik, namun kenyataannya, Muhammadiyah tetap saja tidak bisa menghindarkan diri dari proses-proses politik bangsa. Dalam perjalanan sejarahnya yang hampir mencapai satu abad, hubungan Muhammadiyah dan politik berlangsung secara dinamis. Haedar Nashir menemukan tiga pola hubungan

20 Muhammad Fuad, "Civil Society in Indonesia: The Potential and Limits of

Muhammadiyah," Sojourn: Journal of Social Issues in Southeast Asia, Vol. 17, No. 22, 2002, h. 133-163.

21 Kuntowijoyo, "Tiga Strategi Pergerakan Islam: Struktural, Kultural, dan Mobilitas Sosial," dalam Nurhadi M. Musawir (ed.), Dinamika Pemikiran Islam dan Muhammadiyah, (Yogyakarta: LPD PP Muhammadiyah, 1996), h. 29. 
Muhammadiyah dan partai politik, yakni formal langsung, personal-tidak langsung, serta netral-murni. ${ }^{22}$ Meskipun terdapat variasi dalam hubungannya dan politik, namun terdapat konsistensi sikap Muhammadiyah untuk terus memosisikan diri sebagai organisasi sosial-keagamaan yang bercorak nonpolitik.

Independensi seperti ini, karena Muhammadiyah dalam mengartikulasikan kepentingan politiknya sekurang-kurangnya mempunyai tiga prinsip dasar. Pertama, aspirasi politik Muhammadiyah disalurkan melalui organisasi politik di luar Muhammadiyah. Kedua, organisasi tersebut tidak memiliki hubungan apapun dengan Muhammadiyah. Dan ketiga, organisasi tersebut didirikan bersama dengan elemen-elemen masyarakat lain. Tiga prinsip ini tidak pernah ditinggalkan, baik pada saat tokoh-tokoh Muhammadiyah merangkap sebagai tokoh puncak Syarikat Islam (SI), saat mendirikan Masyumi pada awal masa kemerdekaan, hingga proses berdirinya PAN pada awal era reformasi.

Dari rangkaian sejarah yang demikian panjang, memang Muhammadiyah sejak awal memiliki keterlibatan dalam politik praktis, yang kadang-kadang bahkan tampak berlebihan. Namun demikian, keterlibatan itu tidak pernah mengendurkan konsistensi Muhammadiyah dalam memegang tiga prinsip di atas. Dalam sejarah, setidaknya Muhammadiyah dua kali harus menegaskan posisinya sebagai gerakan sosial-keagamaan yang bersifat non-politik.

Pertama, pada 1962 Muhammadiyah menyusun konsep Kepribadian Muhammadiyah, sebagai hasil keputusan Muktamar setengah abad di Jakarta. Konsep ini berisi identitas Muhammadiyah sebagai gerakan Islam yang bergerak dalam bidang dakwah amar makruf nahi munkar. Konsep ini merupakan upaya Muhammadiyah untuk menegaskan "clearing of self" sebagai akibat keterlibatannya yang terlalu jauh dalam Masyumi, setelah Masyumi dipaksa membubarkan diri oleh Soekarno pada 1960.

Kedua, pada 1971, Muhammadiyah menyusun konsep Khittah Perjuangan Muhammadiyah, sebagai hasil keputusan Muktamar ke-38 di Makassar. Konteks sejarah dari khittah ini adalah penolakan rezim Orde Baru untuk merehabilitasi Masyumi, intervensi Suharto yang terlalu dalam terhadap Parmusi (di mana Masyumi dan Parmusi banyak didukung oleh pimpinan Muhammadiyah), serta represi politik Orde Baru yang sangat massif untuk memenangkan Golkar pada pemilu 1971.

22 Haedar Nashir, Dinamika Politik Muhammadiyah, Bab I, h. 25-55. 
Konsistensi sebagai organisasi sosial-keagamaan non-politik tersebut membuat Muhammadiyah secara umum tampak melakukan apa yang disebut oleh Azyumardi Azra sebagai political disengagement. ${ }^{23}$ Namun sikap politik seperti ini memiliki konsekuensi karena memungkinkan terjadinya pemencaran aspirasi dan pilihan politik warga Muhammadiyah dalam berbagai partai politik, tidak hanya pada partai-partai Islam tetapi juga partai-partai "sekuler". Sebagai akibatnya, tidak ada satu partai manapun yang dapat diidentifikasikan sebagai partainya orang Muhammadiyah. Meskipun selama ini ada anggapan umum bahwa PAN merupakan kendaraan politik utama warga Muhammadiyah.

Namun demikian, sikap netral ini harus diiringi dengan keterlibatan Muhammadiyah secara aktif dalam berbagai persoalan politik kebangsaan. Muhammadiyah harus senantiasa memainkan peranan politiknya sebagai wujud dari dakwah amar makruf nahi munkar dengan jalan memengaruhi proses dan kebijakan negara agar tetap berjalan sesuai dengan konstitusi dan cita-cita luhur bangsa. Dalam hal ini, keterlibatan Muhammadiyah bukan dalam kerangka politik praktis, namun lebih pada upaya memengaruhi proses pengambilan kebijakan agar lebih berpihak kepada kepentingan masyarakat luas.

Prinsip ini memiliki sejumlah kesamaan dengan konsep high politics yang dikembangkan Amien Rais. Menurut Amien Rais, high politics adalah politik yang luhur, adiluhung dan berdimensi moral serta etis, yang terwujud (misalnya) dalam sikap tegas terhadap korupsi, mengajak masyarakat luas untuk memerangi ketidakadilan, serta mendorong proses demokratisasi. Lawan high politics adalah low politics, yang oleh Amien Rais diartikan sebagai politik yang terlalu praktis dan seringkali cenderung nista. Manifestasinya antara lain: melakukan manuver politik untuk memperebutkan kursi legislatif maupun eksekutif, membuat kelompok penekan, membangun lobi, serta berkasakkusuk untuk mempertahankan atau memperluas vested interests. Inti dari low politics adalah power politics. ${ }^{24}$

Muhammadiyah lebih mengedepankan sikap akomodatif terhadap negara, tetapi pada saat yang sama bersikap kritis untuk mengontrol kebijakan pemerintah.

23 Azyumardi Azra, "Muhammadiyah dan Negara: Tinjauan Teologis-Historis", dalam Edy Suandi Hamid, M. Dasron Hamid, Sjafri Sairin (ed.), Rekonstruksi Gerakan Muhammadiyah pada Era Multiperadaban, (Yogyakarta: UII Press, 2000), h. 11-18.

24 Lihat, M. Amien Rais, "High Politics", dalam Kelompok Studi Lingkaran, Intelektualisme Muhammadiyah: Menyongsong Era Baru, (Bandung: Mizan, 1995), h. 74-75. 
Contoh paling tepat dari prinsip politik ini adalah sikap Amien Rais pada fase akhir rezim Orde Baru. Meskipun sering melontarkan pernyataan-pernyataan kritis terhadap pemerintah, Amien menyatakan bahwa Muhammadiyah masih mendukung pemerintah Orde Baru, meskipun bukan dukungan tanpa reserve. Sebagai gerakan moral, kepentingan politik Muhammadiyah adalah agar pemerintah berjalan lurus, berorientasi pada kepentingan rakyat, dan mampu memberantas KKN. Muhammadiyah, kata Amien Rais, akan mendukung Orde Baru jika pemerintah komitmen melaksanakan hal ini. Jika Orde Baru tidak sanggup menanggulangi KKN, tidak lagi peka terhadap kesenjangan sosial-ekonomi, maka Muhammadiyah "hanya bisa mendoakan mudah-mudahan Orde Baru dilindungi oleh Allah". ${ }^{25}$

Prinsip ini hampir serupa dengan konsep oposisi loyal yang diajukan Nurcholish Madjid. Bagi Cak Nur, oposisi diarahkan kepada pemerintah dan kepada aktor penyelenggara negara, akan tetapi loyal kepada negara dan loyal kepada cita-cita bersama. ${ }^{26}$ Dalam konsepsi ini, oposisi tidak sekadaar to oppose, akan tetapi juga to support. Artinya, oposisi bukan berarti asal menentang terus, akan tetapi jika pemerintah melakukan hal yang baik, maka harus didukung.

Perbedaan konsep oposisi loyal dengan prinsip akomodatif-kritis terletak dalam dua hal, yakni aktor dan penekanan. Konsep oposisi loyal diperankan oleh partai politik di luar the ruling parties dan kelompok-kelompok penekan (pressure groups), dengan penekanan pada sikap oposan dan kritis terhadap setiap kebijakan pemerintah. Sementara itu, prinsip akomodatif-kritis diperankan oleh organisasi sosial keagamaan dengan penekanan pada sikap akomodatif terhadap negara dan bersikap kritis jika pemerintah melakukan abuse of power.

Prinsip akomodatif-kritis ini menyebabkan konstruksi civil society yang dikembangkan Muhammadiyah lebih dekat dengan pendekatan Hegelian, yang memiliki ciri (1) lebih menekankan fungsi komplementatif dan suplementatif. Dengan ciri seperti ini, civil society berfungsi melaksanakan sebagian fungsi-fungsi negara (untuk menyediakan fasilitas pendidikan, kesehatan, dan pelayanan sosial bagi masyarakat). (2) Menekankan pentingnya kelas menengah yang sedikit banyak tergantung pada negara. Kelas menengah

25 M. Amien Rais, "Dukungan Muhammadiyah pada Orde Baru," Suara Muhammadiyah, No. 19/18/1996, 1-15 Oktober 1996, h. 7.

26 Nurcholish Madjid, Dialog Keterbukaan, (Jakarta: Paramadina, 1998), h. 7. 
ini terutama bukan karena peranannya dalam bidang ekonomi dan dunia usaha, akan tetapi berkat tangga naik sosial yang disediakan oleh lembaga pendidikan. Mereka banyak bergerak dalam sektor pendidikan dan birokrasi negara. ${ }^{27}$

Meskipun lebih menekankan pada fungsi komplementatif dan suplementatif, prinsip akomodatif-kritis meniscayakan Muhammadiyah untuk tetap mempertahankan independensinya dari kekuasaan dan kontrol negara agar tidak memiliki beban apapun ketika harus menjadi kekuatan kritis terhadap penyelewengan kekuasaan negara. Pengembangan bidang pendidikan, kesehatan, dan pelayanan sosial harus berorientasi pada pengembangan ruang publik yang bebas (free public sphere) di luar negara, serta mengembangkan independensi terhadap negara baik dalam konteks politik maupun ekonomi.

Setelah diuraikan mengenai pokok-pokok pandangan Muhammadiyah tentang politik, pada bagian berikut akan dijelaskan bagaimana Muhammadiyah memberikan panduan bagi warganya dalam melakukan artikulasi dalam kancah politik kekuasaan.

\section{Landasan Artikulasi Politik}

Selain berisi pandangan Muhammadiyah yang sangat mendasar mengenai politik, rumusan pemikiran politik Muhammadiyah sebagaimana telah diuraikan di bagian terdahulu, juga memuat beberapa pemikiran politik yang dapat dijadikan sebagai panduan umum bagi artikulasi politik warga Muhammadiyah dalam ranah politik praktis. Hal ini tentu dimaksudkan agar warga Muhammadiyah yang melibatkan diri dalam ranah politik praktis selalu menjunjung nilai-nilai utama, dan tidak tergelincir dalam tindakan-tindakan tercela.

\section{Warga Muhammadiyah Harus Aktif Berpartisipasi Politik dan Tidak Boleh Berskap Apolits}

Harus diakui bahwa Khittah Perjuangan Muhammadiyah yang menegaskan tentang netralitas politik memang bukan tanpa pengaruh negatif bagi warga

27 Pramono U. Tanthowi, "Muhammadiyah dan NU dalam Kompetisi Makna Civil Society”, Kompas, 6 Juli 2001. 
Muhammadiyah sendiri. Dalam perkembangannya timbul kecenderungan di sebagian warga Muhammadiyah untuk bersikap negatif terhadap politik, bersikap apolitik, serta memandang politik bukan sebagai bagian dari keniscayaan bagi umat Islam. Gejala alergi politik seperti ini tampaknya merupakan akibat dari pemahaman dan pemaknaan atas Khittah Perjuangan Muhammadiyah secara verbalistik bahwa Khittah berarti menjauh dari dunia politik sepenuhnya.

Padahal, sesuai dengan Pedoman Islami Warga Muhammadiyah, seharusnya setiap anggota organisasi ini memahami bahwa wilayah politik dalam kehidupan berbangsa dan bernegara sesungguhnya merupakan salah satu aspek dari ajaran Islam dalam urusan keduniaan (al-umur al-dunyawiyyah). Tentu bukan politik dalam arti perjuangan untuk semata-mata memperebutkan kekuasaan, tetapi politik dalam arti perjuangan terus-menerus untuk mendorong terciptanya tatanan politik yang lebih demokratis, tegaknya keadilan sosial, serta terwujudnya kesejahteraan masyarakat yang lebih luas.

\section{Warga Muhammadiyah Harus Mengedepankan Etika Dalam Melakukan Aktivitas Politik}

Kebebasan untuk menentukan hak politik,sebagaimana dinyatakan dalam Khittah Perjuangan Muhammadiyah, seharusnya dilaksanakan secara bertanggung jawab, rasional, kritis, yang senantiasa dibingkai, dimotivasi, dan dijiwai oleh nilai-nilai luhur agama dan moral yang utama. Karena itu, warga Muhammadiyah yang aktif dalam politik harus mengedepankan tanggung jawab (amanah), akhlak mulia, keteladanan, serta perdamaian (ishlah). Dengan demikian, maka para politisi Muhammadiyah dapat menampilkan keteladanan diri (uswah hasanah) sebagai politisi yang berkarakter cerdas, anti-korupsi, dan hidup sederhana. Sifat-sifat keutamaan seperti ini telah dimiliki secara turuntemurun oleh para politisi Islam modernis. Sehingga, mereka memperoleh atribut berupa sifat-sifat yang utama, yakni berprinsip, jujur, konsekuen, dan berpengalaman. ${ }^{28}$

Di sisi lain, sebagai konsekuensi dari kebebasan dalam hak pilih, warga Muhammadiyah harus mempertimbangkan kesatuan gerak di bawah satu komando kepemimpinan. Meskipun pilihan politik warga Muhammadiyah

28 Allan A. Samson, "Conception of Politics, Power, and Ideology in Contemporary Indonesian Islam," dalam Karl D. Jackson dan Lucian W. Pye (ed.), Political Power and Communication in Indonesia, (Berkeley: University of California Press, 1978), h. 202. 
tersebar dalam berbagai partai, namun seluruh aktivitas politik tersebut harus sejalan dengan upaya memperjuangkan misi Persyarikatan dalam melaksanakan dakwah amar makruf nahi munkar. Oleh karena itu, warga Muhammadiyah harus memegang tradisi taat asas. Artinya, jika sudah ada keputusan organisasi melalui hasil musyawarah, maka seluruh warga Persyarikatan harus menghormati dan melaksanakannya. Ini bukan berarti bahwa Muhammadiyah tidak memberi ruang bagi perbedaan pendapat. Karena, wilayah kebebasan ekspresi politik yang diberikan bagi warga Muhammadiyah masih sangat besar, sementara keputusan organisasi biasanya diambil hanya menyangkut prinsip-prinsip dasar dan strategis. Kalaupun masih ada dissenting opinion, Muhammadiyah tetap tidak memiliki hak untuk memaksa warganya tunduk kepada keputusan.

\section{Warga Muhammadiyah Dalam Melakukan Aktivitas Politik Harus Berorientasi Pada Kepentingan Umum, Bukan Kepentingan Diri Sendiri dan Golongan}

Sebagai konsekuensi dari keharusan menampilkan keteladanan diri, maka para politisi Muhammadiyah harus mengorientasikan visi politiknya pada terwujudnya kesejahteraan rakyat dan terciptanya tatanan politik yang demokratis. Para politisi Muhammadiyah tidak boleh mengorbankan kepentingan umum demi kepentingan pribadi, atau kepentingan kelompok yang sempit. Termasuk kepentingan Persyarikatan sendiri. Para politisi Muhammadiyah tidak boleh menjadikan politik (meminjam istilah Buya Syafii Maarif) "sekadar mata pencaharian”.

Selain itu, para politisi Muhammadiyah tidak boleh terdiri dari para politisi yang sering disebut Buya Syafii Maarif sebagai para "politisi rabun ayam" yang wawasannya "tidak lebih luas dari halaman rumahnya". Buya Syafii Maarif mengatakan bahwa para politisi rabun ayam ini layaknya memiliki mata kelelawar. Di saat gelap, mata kelelawar menjadi terang karena banyak rizki yang dapat disambar tanpa memperhitungkan siapa yang punya. ${ }^{29}$ Sebaliknya, lanjut Buya Syafii Maarif, para politisi Muhammadiyah harus memiliki wawasan kebangsaan sekaligus memiliki kepekaan nurani, dan "bersama dengan kekuatan siuman lain untuk secepatnya memulihkan kepekaan

29 Khutbah Iftitah Ketua PP Muhammadiyah dalam Sidang Tanwir Muhammadiyah di Mataram, NTB, 2-5 Desember 2004, h. 2. 
moral, sehingga akal sehat dan hati nurani menjadi pemenang tunggal bagi masa depan Indonesia." ${ }^{30}$

\section{Artikulasi Politik Warga Muhammadiyah Harus Menunukan Sikap Politik Moderat}

Sebagai konsekuensi dari gerakan Muhammadiyah yang non-politik dengan strategi kultural, maka aspirasi politik warga Muhammadiyah harus bersifat obyektif, seperti mendorong proses demokratisasi, kesejahteraan rakyat, good governance, penegakan hukum, pembangunan ekonomi yang berkeadilan, dan sebagainya. Para politisi Muhammadiyah tidak boleh mengartikulasikan aspirasi politiknya dalam platform yang legalistik-formalistik-eksklusif dengan mengedepankan bahasa dan simbol keagamaan yang kental.

Aspirasi politik eksklusif sangat tidak menguntungkan bagi masa depan politik Islam di Indonesia. Pertama, karena akan memancing munculnya reaksi dari kalangan nasionalis dan non-Islam, sehingga dapat memicu bangkitnya sentimen politik aliran di Indonesia, yang sebenarnya telah mengalami proses mencair sejak paruh kedua era Orde Baru. Hal ini jelas tidak menguntungkan masa depan politik Islam di Indonesia. Karena, selain tidak sesuai dengan situasi keragaman sosial-budaya dan keagamaan masyarakat, juga sangat memungkinkan akan menimbulkan ketegangan-ketegangan baru antar pendukung religio-politik di Indonesia.

Kedua, aspirasi politik yang eksklusif juga akan menimbulkan reaksi yang sama dari kalangan Islam sendiri, karena sebagian umat Islam telah mengalami transformasi pemikiran dan perilaku politik sehingga tidak lagi mengedepankan strategi politik legalistik-formalistik. ${ }^{31} \mathrm{Jika}$ perbedaan pendapat di antara kekuatan-kekuatan politik Islam semakin menguat, maka akan memicu munculnya benturan konflik internal ummat Islam di Indonesia sendiri. Selain itu, artikulasi politik yang moderat dan obyektif dengan sendirinya akan menghilangkan kecurigaan bahwa kekuatan politik Islam berniat untuk membajak proses demokrasi demi aspirasi politik yang eksklusif.

30 Ibid., h. 4.

31 Bahtiar Effendy, Islam and the State: The Transformation of Islamic Political Ideas and Practices in Indonesia, (Singapore: ISEAS, 2002). 


\section{Penutup}

Muhammadiyah merupakan salah satu komponen bangsa yang memiliki posisi dan peran yang sangat strategis. Muhammadiyah dapat memainkan peran politik sebagai kekuatan politik yang ikut memengaruhi proses politik nasional secara signifikan, tanpa harus mengubah jati dirinya menjadi organisasi partai politik. Dalam kapasitasnya sebagai organisasi sosial keagamaan, Muhammadiyah harus mampu menampilkan diri dengan artikulasi politik yang lebih efektif, sebagai wujud tanggung jawab moral dalam ikut serta mengarahkan jalan sejarah bangsa ini menuju masa depan Indonesia yang adil, makmur, demokratis, dan berkeadaban. Insya Allah. 


\section{Daftar Pustaka}

Abdullah, M. Amin, Dinamika Islam Kultural, (Bandung: Mizan, 2000).

Alfian, Muhammadiyah: the Political Behaviour ofa Muslim Modernist Organization under Dutch Colonialism, (Yogyakarta: Gajah Mada University Press, 1989).

Azra, Azyumardi, "Muhammadiyah dan Negara: Tinjauan Teologis-Historis", dalam Edy Suandi Hamid, M. Dasron Hamid, Sjafri Sairin (ed.), Rekonstruksi Gerakan Muhammadiyah pada Era Multiperadaban, (Yogyakarta: UII Press, 2000).

Effendy, Bahtiar, Islam and the State: The Transformation of Islamic Political Ideas and Practices in Indonesia, (Singapore: ISEAS, 2002).

Fachruddin, KH., "Muhammadiyah dan Politik", dalam Departemen Penerangan RI, Makin Lama Makin Tjinta: Muhammadiyah Setengah Abad 1912-1262, (Jakarta: Departemen Penerangan, 1963).

Fuad, Muhammad, "Civil Society in Indonesia: The Potential and Limits of Muhammadiyah," Sojourn: Journal of Social Issues in Southeast Asia, Vol. 17, No. 22, 2002.

Jung, Eunsook, "Islamic Organizations and Electoral Politics in Indonesia: The Case of Muhammadiyah," Southeast Asia Research, Vol. 22, No. 1.

Khutbah Iftitah Ketua PP Muhammadiyah dalam Sidang Tanwir Muhammadiyah di Mataram, NTB, 2-5 Desember 2004.

Kuntowijoyo, "Tiga Strategi Pergerakan Islam: Struktural, Kultural, dan Mobilitas Sosial,” dalam Nurhadi M. Musawir (ed.), Dinamika Pemikiran Islam dan Muhammadiyah, (Yogyakarta: LPD PP Muhammadiyah, 1996).

Madjid, Nurcholish, Dialog Keterbukaan, (Jakarta: Paramadina, 1998).

Nashir, Haedar, Dinamika Politik Muhammadiyah, (Yogyakarta: Bigraf Publishing, 2000).

Perilaku Politik Elite Muhammadiyah, (Yogyakarta: Tarawang, 2000).

Muhammadiyah Gerakan Pembaruan, (Yogyakarta: Suara Muhammadiyah, 2010).

Pasha, Musthafa Kamal dan Ahmad Adaby Darban, Muhammadiyah sebagai Gerakan Islam dalam Perspektif Historis dan Ideologis, (Yogyakarta: LPPI, 2002).

PP Muhammadiyah, Berita Resmi Muhammadiyah, No. 02/2002.

PP Muhammadiyah, Pedoman Hidup Islami Warga Muhammadiyah, (Yogyakarta: 
Suara Muhammadiyah, 2000).

Puar, Yusuf Abdullah, Perjuangan dan Pengabdian Muhammadiyah, (Jakarta: Pustaka Antara, 1989).

Rais, M. Amien, "High Politics", dalam Kelompok Studi Lingkaran, Intelektualisme Muhammadiyah: Menyongsong Era Baru, (Bandung: Mizan, 1995).

"Dukungan Muhammadiyah pada Orde Baru," Suara Muhammadiyah, No. 19/18/1996, 1-15 Oktober 1996.

Samson, Allan A., "Conception of Politics, Power, and Ideology in Contemporary Indonesian Islam,” dalam Karl D. Jackson dan Lucian W. Pye (ed.), Political Power and Communication in Indonesia, (Berkeley: Univerrsity of California Press, 1978).

Soebagyo, LN., KH Mas Mansur Pembaharu Islam Indonesia, (Jakarta: Gunung Agung, 1982).

Sulistiyanto, Priyambudi, "Muhammadiyah, Local Politics, and Local Identity in Kotagede," Sojourn: Journal of Social Issues in Southeast Asia, Vol. 21, No. 2, 2006.

Syaifullah, Gerak Politik Muhammadiyah dalam Masyumi, (Jakarta: Pustaka Utama Grafiti, 1997).

Syamsuddin, M. Din, Religion and Politics in Islam: The Case of Muhammadiyah in Indonesia's New Order, Ph.D. Dissertation at University of California Los Angeles, 1991.

Tanthowi, Pramono U., "Muhammadiyah dan NU dalam Kompetisi Makna Civil Society", Kompas, 6 Juli 2001. 